\title{
WIGGLE-MATCH DATING OF WOODEN SAMPLES FROM IRON AGE SITES IN NORTHERN ITALY
}

\author{
G Quarta $^{1,2} \bullet \mathrm{M} \mathrm{I} \mathrm{Pezzo}^{3} \bullet \mathrm{S} \mathrm{Marconi}^{3} \bullet \mathrm{U}^{\text {Tecchiati }^{4}} \bullet \mathrm{M} \mathrm{D}^{\prime}$ Elia $^{1} \bullet \mathrm{L} \mathrm{Calcagnile}^{1}$
}

ABSTRACT. Archaeological excavations carried out at the sites of Laion/Lajen (Bolzano/Bozen) and Stufles-Oberegger (Bressanone/Brixen) in northern Italy uncovered well-preserved wooden samples in cultural layers archaeologically dated to the Iron Age. From the 2 sites, different wooden samples were recovered that were well preserved enough to allow clear identification of the tree species and of the ring structure. Among the different wooden samples, 2 were selected for radiocarbon analyses: from Laion/Lajen, a beam with an unbroken sequence of 158 rings; from Stufles-Oberegger, a combusted trunk with a sequence of 217 rings. Both samples were identified as Larix decidua species. From each sequence, single rings were selected and submitted for accelerator mass spectrometry (AMS) ${ }^{14} \mathrm{C}$ dating analysis at CEDAD. Conventional ${ }^{14} \mathrm{C}$ ages were then calibrated to calendar ages using the IntCal04 atmospheric data set, while the statistical constraints resulting from the defined ring sequence were used to develop a wiggle-matching approach by making use of the Bayesian analysis functions available in OxCal. The obtained results are an important contribution in refining the chronology of the studied sites.

\section{INTRODUCTION}

The development and routine application of Bayesian methods for analyzing multiple radiocarbon dates can be regarded as one of the most important developments in the ${ }^{14} \mathrm{C}$ dating method and of its applications in different research fields (Buck et al. 1991; Bronk Ramsey 2009). The application of Bayesian-based methods for modeling of sequences of ${ }^{14} \mathrm{C}$ dates has had such a profound impact in archaeological sciences that Bayliss (2009) describes it as a "third radiocarbon revolution.” The potentialities of these methods are particularly evident in those periods where, because of the flat shape of the calibration curve, the chronological resolution achievable with a single ${ }^{14} \mathrm{C}$ measurement is usually poor. In several cases, this makes ${ }^{14} \mathrm{C}$ dating to solve chronological issues problematic (Blackwell et al. 2006).

Nevertheless, analysis of multiple ${ }^{14} \mathrm{C}$ dates with known temporal relationships among them can significantly enhance the achievable chronological resolution. An example in which the relationships between calendar ages of different samples is known is represented by the sequences of annual tree rings. Therefore, use of the "wiggle matching" approach for high-resolution dating of tree-ring sequences has been increasingly applied (e.g. Manning and Weninger 1992; Manning et al. 2001; Vasiliev et al. 2001; Galimberti et al. 2004). The mathematical foundations of the method are well developed (Steier and Rom 2000; Bronk Ramsey et al. 2001) and user-friendly functions are now available in calibration software such as OxCal (Bronk Ramsey 1995, 2001). Here, we present the ${ }^{14} \mathrm{C}$ dating results from 2 tree-ring sequences recovered from cultural contexts attributed to the Iron Age from 2 archaeological sites: Laion/Lajen and Stufles-Oberegger, province of Bolzano/Bozen, South Tyrol, northern Italy (Figure 1). The aim of the study was to obtain information about the chronology of these 2 sites and to improve the chronological resolution by ${ }^{14} \mathrm{C}$ dating for a time range falling in the Hallstatt plateau (about $800-400$ cal BC) of the ${ }^{14} \mathrm{C}$ calibration curve. Indeed, calibration of single ${ }^{14} \mathrm{C}$ measurements in this time period, even with the highest possible instrumental precision in conventional ${ }^{14} \mathrm{C}$ age determination, results in wide calibrated time ranges often

\footnotetext{
${ }^{1}$ CEDAD (Centre for Dating and Diagnostics), Department of Innovation Engineering, University of Salento, Lecce, Italy. ${ }^{2}$ Corresponding author. Email: gianluca.quarta@unisalento.it.

${ }^{3}$ Museo Civico di Rovereto, Dendrochronology Laboratory, Rovereto, Italy.

${ }^{4}$ Soprintendenza Provinciale ai Beni Culturali di Bolzano/Bozen/Bozen, Ufficio Beni Archeologici, Bolzano/Bozen, Italy.
}

(C) 2010 by the Arizona Board of Regents on behalf of the University of Arizona Proceedings of the 20th International Radiocarbon Conference, edited by A J T Jull RADIOCARBON, Vol 52, Nr 2-3, 2010, p 915-923 
extending for the whole plateau at the 95\% confidence level (Blockley et al. 2007). This study also aimed to confirm previous results obtained by dendrochronology on the same samples.

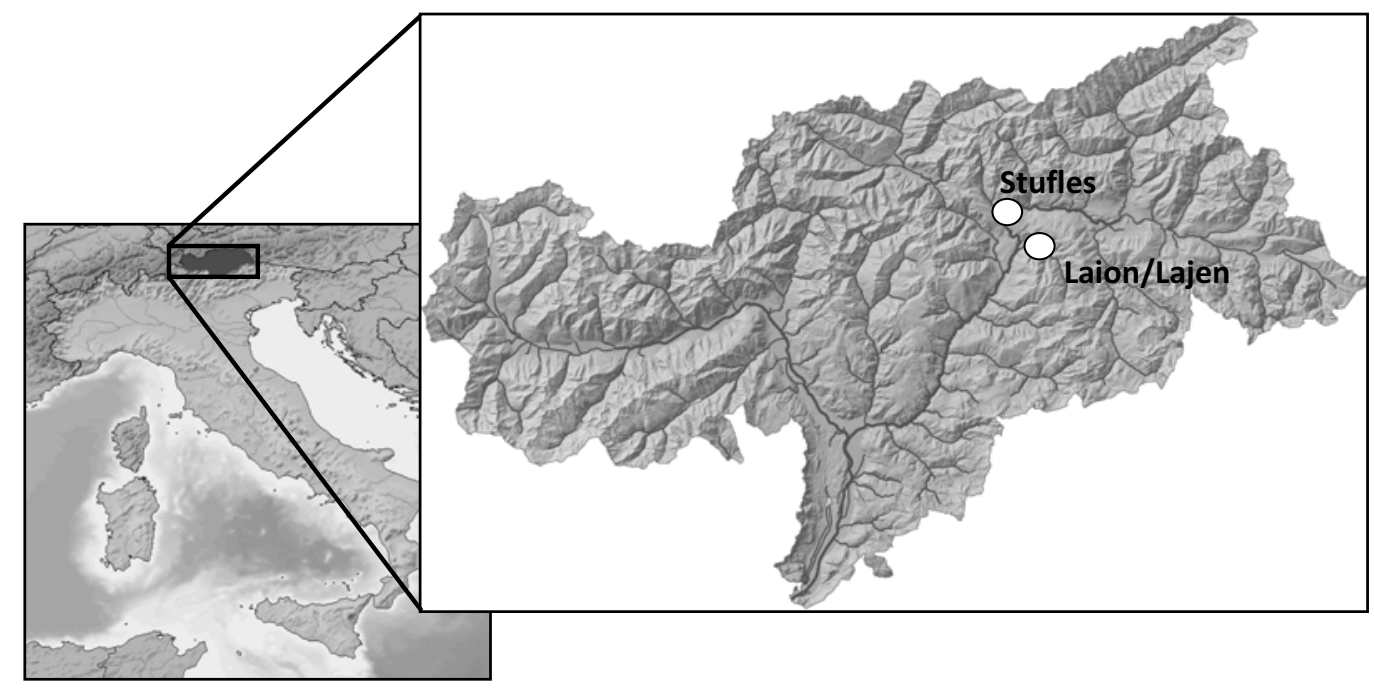

Figure 1 Map of South Tyrol (northern Italy) with locations of the 2 studied sites indicated

\section{ARCHAEOLOGICAL INFORMATION AND STUDIED SITES}

The Soprintendenza ai Beni Culturali of the province of Bolzano/Bozen carried out several excavations in the last $35 \mathrm{yr}$ in South Tyrol, northern Italy, which revealed the remains of dozens of buildings dated, based on analysis of associated archaeological material, to different periods of the Iron Age (1st millennium BC), in particular, between the 6th-4th centuries BC. These buildings were typically built on a masonry basement with local wood, assembled following the Blockbau technique. In some cases, the archaeological excavations brought to light very well-preserved wooden remains characterized by a large number of rings, which suggested the possibility to use them for dendrochronology and wiggle-match ${ }^{14} \mathrm{C}$ dating. A research project was begun to the study such tree-ring sequences with the aim of obtaining a highly accurate chronological framework for the sites, and in particular to better define the end of the Hallstatt period (12th-6th centuries BC) and of the "La Tène" age (6th-1st centuries BC) in this region. On-site sample collection was carried out by the office of the local Soprintendenza in collaboration with the Archaeological Research Society of Bressanone/Brixen.

In this paper, we present the results obtained in the analysis of wood remains recovered in the archaeological sites of Laion/Lajen and Stufles, northern Italy. In Laion/Lajen, the excavations uncovered a large village that occupied the top and slopes of a hill, the Wasserbühel ("Hill of the Water"), located near the confluence of the Rio Gardena and River Isarco. The hill slopes were terraced during the Bronze Age and then repeatedly occupied by residential wooden structures (dated to the Middle and Recent Bronze Age) or plinth base masonry archaeologically dated to the recent Iron Age. A prolonged Roman occupation, until the beginning of the Middle Ages, concludes the stratigraphy of the sites, while sporadic finds (such as an anthropomorphic statue) dating back to the Neolithic and the recent Copper Age suggest an early occupation of the area between the 5th and 3rd millennium BC. The strategic geographic position, the repeated occupation of the area through the 
centuries, and the nature and quality of the findings suggest, from an archaeological point of view, that Laion/Lajen may have played a central role in the region.

The immediate surroundings of the hill are characterized by a large area with stagnant water generating a marshy soil. The humid environment has probably contributed to the optimal preservation of the wooden elements belonging to buildings that have been archaeologically dated, based on analysis of the associated diagnostic material, to the ancient Ceramic Phase of the Rhaetian-Fritzens-Sanzeno culture, whose beginnings are placed in the late 6th century BC (late Hallstatt age).

Stufles is a historical district in the town of Bressanone/Brixen, located in the center of the Isarco Valley, where the valley bottom broadens at the confluence of the Isarco and Rienza watercourses. The climate of the area is particularly favorable due to the morenic plateau to the north, which protects it against cold northern winds, while eastwardly sloping uplands give constant exposure to the sun, even during the winter months. These features combined with the stable hydrological conditions contribute to create an optimal location for human settlement. Indeed, there are traces of uninterrupted human occupation in the Bressanone/Brixen area from the Neolithic until the present day. In the recent Iron Age, in the late 6th century BC, the area was occupied by a large settlement of houses lasting up to the Romanization period, which occurred in this region during the 1st century BC and ended around $15 \mathrm{BC}$ with the campaign of Tiberius and Drusus against the local population. Archaeological excavations in Stufles revealed epigraphic evidence (alphabet of Bolzano/Bozen, north Etruscan type), remains of a massive fortification wall, a road crossing the village, and remains of ancient buildings. Local buildings consisted mostly of 2 stories, with a basement created by a stone perimeter wall covered with timber (Feltrin et al. 2008). The floors of the structures were supported by cross-beams resting on alignments embedded in the walls.

During archaeological excavations in 3 different buildings, a layer containing charred beams, poles, and planks was found. The buildings were likely destroyed by a fire that caused the collapse of the ceiling supported by wooden beams and composed of gravel material. This process probably led to a slowing down of the combustion process, which took place in an oxygen-poor environment. Consequently, the wooden material was carbonized and perfectly preserved (Pezzo 2009).

\section{MATERIALS AND METHODS}

In total, 110 samples were selected for identification and measurement of ring widths. Dendrochronological analysis was carried out at the Dendrochronology Laboratory of the Museo Civico of Rovereto. Particular care was taken for the collection of samples found in a humid environment, which were stored in water until dendrochronological analysis and after that submitted to final restoration and conservation processes.

For dendrochronological analysis, the sample surfaces were prepared using a razor blade in order to enhance surface resolution. Ring widths were measured via optical microscope to the nearest 0.01 mm using a LINTAB measuring device. Data were then collected and analyzed using the software TSAP (Rinn 1996). Cross-dating was obtained by visual inspection of the curves and by time series statistics through the evaluation of dendrochronological statistical parameters such as $t_{\mathrm{BP}}$ (Baillie and Pilcher 1973), Gleichläufigkeit GLK\% (Eckstein and Bauch 1969), and $t_{\mathrm{HO}}$ values (Hollstein 1980).

From Laion/Lajen, 30 timbers with rings ranging between 12 and 158 were submitted to dendrochronological analysis, while the timber with the longest ring sequence was selected for wigglematch ${ }^{14} \mathrm{C}$ dating. This timber was a 44-cm-long beam (maximum width $34 \mathrm{~cm}$, maximum height 8 cm) (LAI-3, Area L-N US831) identified as belonging to the Larix decidua species (larch). Wood 
identification was carried out according to the microscopic anatomical features of the samples, which were analyzed both in the radial and transverse sections. The radial section revealed longitudinal tracheids with biseriate pits, heterocellular rays and piceoid pits in the cross fields of the early wood. The transverse section showed resin canals with thick-walled epithelial cells and an abrupt transition from early to late wood. Sapwood was not visible in the sample. The beam showed an unbroken sequence of 158 rings from which 4 single-ring fragments were collected corresponding to ring numbers 1-2, 49-50, 90-100, and 150 (Table 1).

Table 1 Analyzed samples, conventional ${ }^{14} \mathrm{C}$ ages and corresponding calibrated time ranges.

\begin{tabular}{|c|c|c|c|c|c|}
\hline & Ring $\mathrm{nr}$ & Lab code & ${ }^{14} \mathrm{C}$ age (yr BP) & Calendar age & Probability \\
\hline \multirow[t]{10}{*}{ Stufles } & \multirow{3}{*}{$1-2$} & \multirow{3}{*}{ LTL3127A } & \multirow{3}{*}{$2570 \pm 35$} & $810-740$ cal BC & $61.4 \%$ \\
\hline & & & & 690-660 cal BC & $13.5 \%$ \\
\hline & & & & $650-550$ cal BC & $20.5 \%$ \\
\hline & \multirow{2}{*}{$49-50$} & \multirow{2}{*}{ LTL3128A } & \multirow{2}{*}{$2535 \pm 35$} & $800-710$ cal BC & $34.4 \%$ \\
\hline & & & & $700-530$ cal BC & $61.0 \%$ \\
\hline & \multirow[t]{3}{*}{ 100-101 } & \multirow[t]{2}{*}{ LTL3129A } & \multirow[t]{2}{*}{$2420 \pm 35$} & $750-680$ cal BC & $16.8 \%$ \\
\hline & & & & $670-640$ cal BC & $4.9 \%$ \\
\hline & & \multirow{3}{*}{ LTL3130A } & \multirow{3}{*}{$2492 \pm 30$} & $600-390 \mathrm{cal} \mathrm{BC}$ & $73.7 \%$ \\
\hline & \multirow[t]{2}{*}{$140-141$} & & & $780-500 \mathrm{cal} \mathrm{BC}$ & $94.3 \%$ \\
\hline & & & & $440-420 \mathrm{cal} \mathrm{BC}$ & $1.1 \%$ \\
\hline \multirow[t]{9}{*}{ Laion/Lajer } & \multirow{3}{*}{$1-2$} & \multirow{3}{*}{ LTL1692A } & \multirow{3}{*}{$2573 \pm 40$} & $820-730$ cal BC & $57.6 \%$ \\
\hline & & & & $690-660$ cal BC & $13.3 \%$ \\
\hline & & & & $650-540$ cal BC & $24.5 \%$ \\
\hline & \multirow[t]{2}{*}{$49-50$} & \multirow[t]{2}{*}{ LTL1693A } & \multirow[t]{2}{*}{$2485 \pm 45$} & $780-480 \mathrm{cal} \mathrm{BC}$ & $87.3 \%$ \\
\hline & & & & $470-410$ cal BC & $8.1 \%$ \\
\hline & \multirow[t]{2}{*}{$90-100$} & \multirow[t]{2}{*}{ LTL1694A } & \multirow[t]{2}{*}{$2462 \pm 40$} & $770-680$ cal BC & $25.2 \%$ \\
\hline & & & & $670-410$ cal BC & $70.2 \%$ \\
\hline & \multirow[t]{2}{*}{150} & \multirow[t]{2}{*}{ LTL1695A } & \multirow[t]{2}{*}{$2455 \pm 40$} & $760-680 \mathrm{cal} \mathrm{BC}$ & $23.6 \%$ \\
\hline & & & & $670-400 \mathrm{cal} \mathrm{BC}$ & $71.8 \%$ \\
\hline
\end{tabular}

In Stufles, 80 timbers with rings ranging between 12 and 217 were recovered. For wiggle-match dating, sample OBR-4, with a sequence of 217 rings, was used. OBR-4 (US 5, Sector C, House 1, wood element 4) is a charred beam of larch (Larix decidua Miller; $8 \mathrm{~cm}$ maximum width, $8.5 \mathrm{~cm}$ length), identified on the basis of microscopic anatomical features of the wood as described above. Sapwood was not visible in this case. Single-ring fragments were selected from rings 1-2, 49-50, 100-101, and $140-141$ for ${ }^{14} \mathrm{C}$ dating (Table 1 ). The building was archaeologically dated, based on the analysis of pottery found in some of the stratigraphic units, to the ancient horizon of the Retica culture, corresponding to the Hallstatt phases D1-D2-D3.

Both sequences were submitted for dendrochronological analysis, the results of which are reported in detail elsewhere (Marconi et al. 2007; Feltrin et al. 2008). It must be noted that due to the lack of a standard Larix decidua reference chronology for northern Italy, cross-dating using the curve constructed by B Becker (Kuniholm 2001) for southern Bavaria was tried. However, since Becker's curve refers to a different species (oak) from a different ecological zone, cross-dating is not straightforward (Haneca et al. 2009). In fact, recently a 9111-yr-long conifer tree chronology (mainly Pinus cembra) has been established for the eastern Alpine region (Nicolussi et al. 2009). A cross-linking to this curve is also not immediate, considering that it refers to high-altitude sites (between 2000 and $2400 \mathrm{~m}$ asl), while the 2 sites in this study are located at lower altitudes, 550 and $\sim 1093 \mathrm{~m}$ asl for Laion/Lajen and Stufles, respectively. 
In fact, the comparison made between the curve obtained for the studied samples and the curve of Becker provided acceptable statistical results ( $\mathrm{t}_{\mathrm{BP}}: 3.7, \mathrm{t}_{\mathrm{HO}}$ : 4.1 Gleichläufigkeit GLK 67\%, overlap = $95 \mathrm{yr}$ ) and led to the dating of the last measurable rings of the 2 sequences to 452 and 481 BC for Laion/Lajen and Stufles, respectively. Nevertheless, the above-mentioned difficulties associated with cross-dating of the samples suggested the need for ${ }^{14} \mathrm{C}$ measurements to confirm the results.

Samples selected for analyses were submitted for AMS ${ }^{14} \mathrm{C}$ dating at CEDAD (Centre for Dating and Diagnostics) at the University of Salento, Lecce, Italy. The samples underwent standard processing procedures usually employed for wood: an initial mechanical cleaning using an optical microscope for removal of macrocontaminants followed by a chemical treatment consisting of alternate acid-alkali-acid washes (AAA method). The purified fractions of the samples were then sealed in quartz tubes together with copper oxide and silver wool and combusted to carbon dioxide at $900{ }^{\circ} \mathrm{C}$ in a muffle oven. The $\mathrm{CO}_{2}$ obtained was cryogenically transferred to a graphitization line where it was reduced at $600{ }^{\circ} \mathrm{C}$ to graphite by using hydrogen as reducing agent and iron powder as catalyst (D'Elia et al. 2004). ${ }^{14} \mathrm{C}$ concentrations and stable carbon isotopic ratios were measured on the 3MV Tandetron accelerator (HVEE 4130HC) at CEDAD (Calcagnile et al. 2005). IAEA C-6 (sucrose) and IAEA C-4 (subfossil wood) standards were used for normalization and for background correction, respectively. Unprocessed graphite from Alfa Aesar was used for measurement of the machine background, which is estimated to be $10^{-16}\left({ }^{14} \mathrm{C} /{ }^{12} \mathrm{C}\right.$ ratio) (Calcagnile and Quarta 2010). The ${ }^{14} \mathrm{C}$ concentrations measured were corrected for mass fractionation by making use of the $\delta^{13} \mathrm{C}$ term measured on-line with the AMS system, and the conventional ${ }^{14} \mathrm{C}$ ages were calculated according to Stuiver and Polach (1977).

\section{RESULTS}

Conventional ${ }^{14} \mathrm{C}$ ages obtained for the samples are reported in Table 1, together with the calendar ages obtained by calibrating single ${ }^{14} \mathrm{C}$ ages using the IntCal04 calibration curve (Reimer et al. 2004) and the OxCal v 4.1 software (Bronk Ramsey 1995, 2001). One can observe that the calibrated ages correspond to wide time ranges with non-Gaussian-shaped statistical distributions. For example, the measured ${ }^{14} \mathrm{C}$ age of sample LTL3129A corresponds to a calendar time range of more than 3 centuries. This is due to the shape of the calibration curve in the considered time range and in particular to the "plateau" corresponding to the period between $~ 800$ and 400 cal BC.

In order to reduce the calibrated time ranges, wiggle-matching analysis was carried out using information regarding the order of the measured tree rings as statistical constraints. Analysis was done in a Bayesian statistical framework through the $D \_$Sequence function in OxCal. Results of the analyses are reported in Figure 2A and 3A for Stufles and Laion/Lajen, respectively. The 2 models showed agreement indexes $\left(\mathrm{A}_{\text {comb }}\right.$ ) of $64.1 \%$ and $112.9 \%$, both above the acceptable threshold of $35 \%$ (corresponding to $1 / \sqrt{2 n}, n$ being the number of measurements) (Bronk Ramsey 1995).

To account for the fact that the youngest measured rings (LTL3130A, ring 140 for Stufles; LTL1695A, ring 150 for Laion/Lajen) did not correspond to the last preserved ring (ring 217 for Stufles and ring 158 for Laion/Lajen) of the analyzed sequence, age gaps of 77 and 8 yr, respectively, were introduced after the last measured ring. In this way, ages for the last preserved rings were extrapolated using the Date function of OxCal. Results for both sites are given in Figures 2 and 3.

The last preserved ring of the sequence from Stufles is thus dated to 610-561, 554-532, 474-447, and $425-376 \mathrm{cal} \mathrm{BC}$ with corresponding probabilities of $67.7 \%, 6.4 \%, 13.8 \%$, and $7.6 \%$ (2- $\sigma$ confidence level). Similarly, the last ring of the sample from Laion/Lajen is dated to 656-579, 532-504, $490-430$, and $424-412 \mathrm{cal}$ BC, with probabilities of 55.3\%, 19.5\%, 18.8\%, and 1.8\%, respectively 

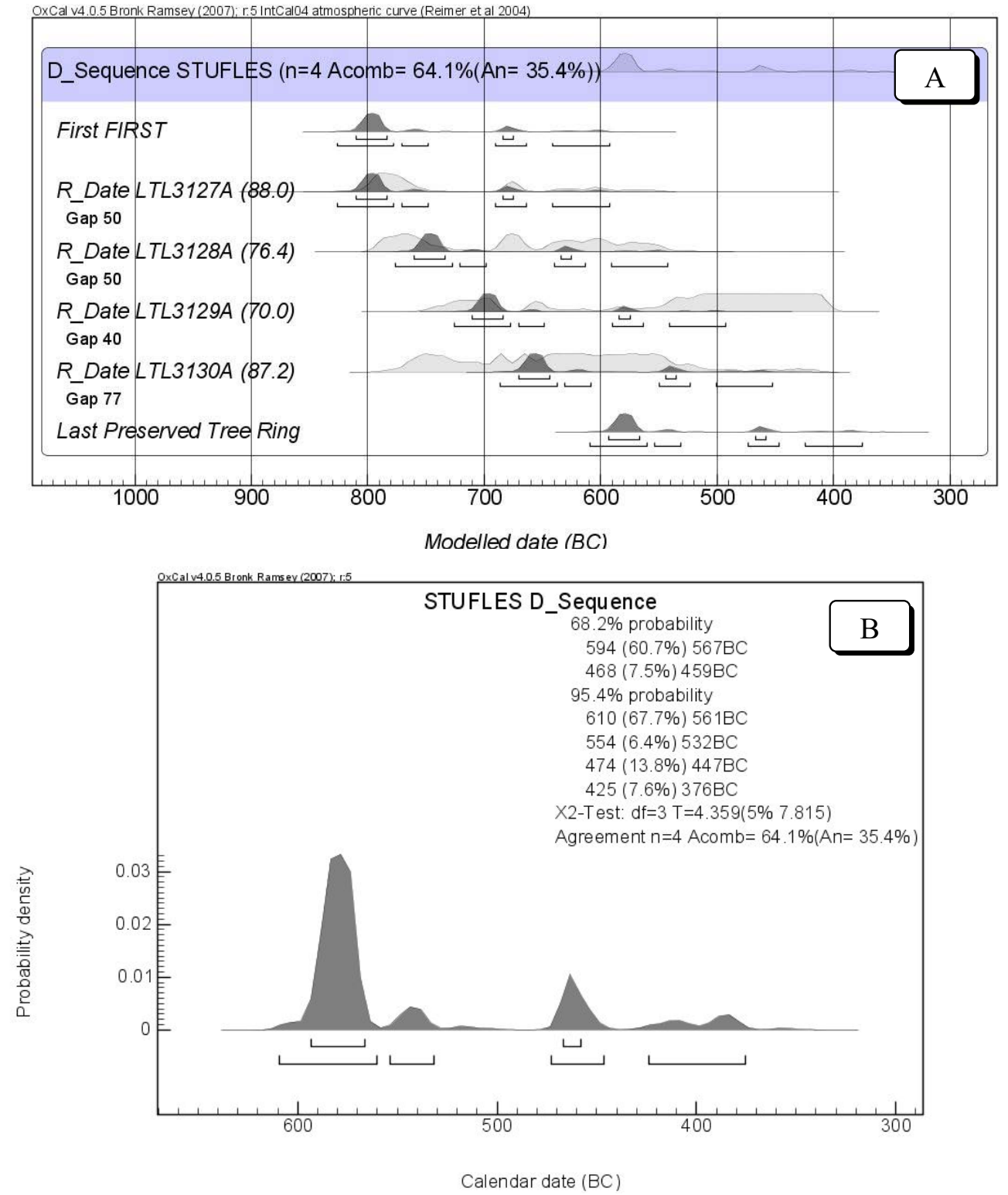

Figure 2 Wiggle-matching results for all samples (A) and for the last preserved ring (B) for the sequence from Stufles

$(2 \sigma)$. We observe that, though the calibrated time ranges still have a multimodal distribution, the calendar ranges obtained for the last ring are reduced from 300 to $140 \mathrm{yr}$ (Stufles) and from 350 to 180 yr (Laion/Lajen).

It is worth noting that since the sapwood and an unknown number of heartwood rings were missing in both the samples studied, the results obtained for the last preserved ring have to be considered a terminus post quem for construction of the buildings. Furthermore, the obtained ${ }^{14} \mathrm{C}$ dates are consistent, within the uncertainties associated with the presented results, with the dendrochronological ages. 

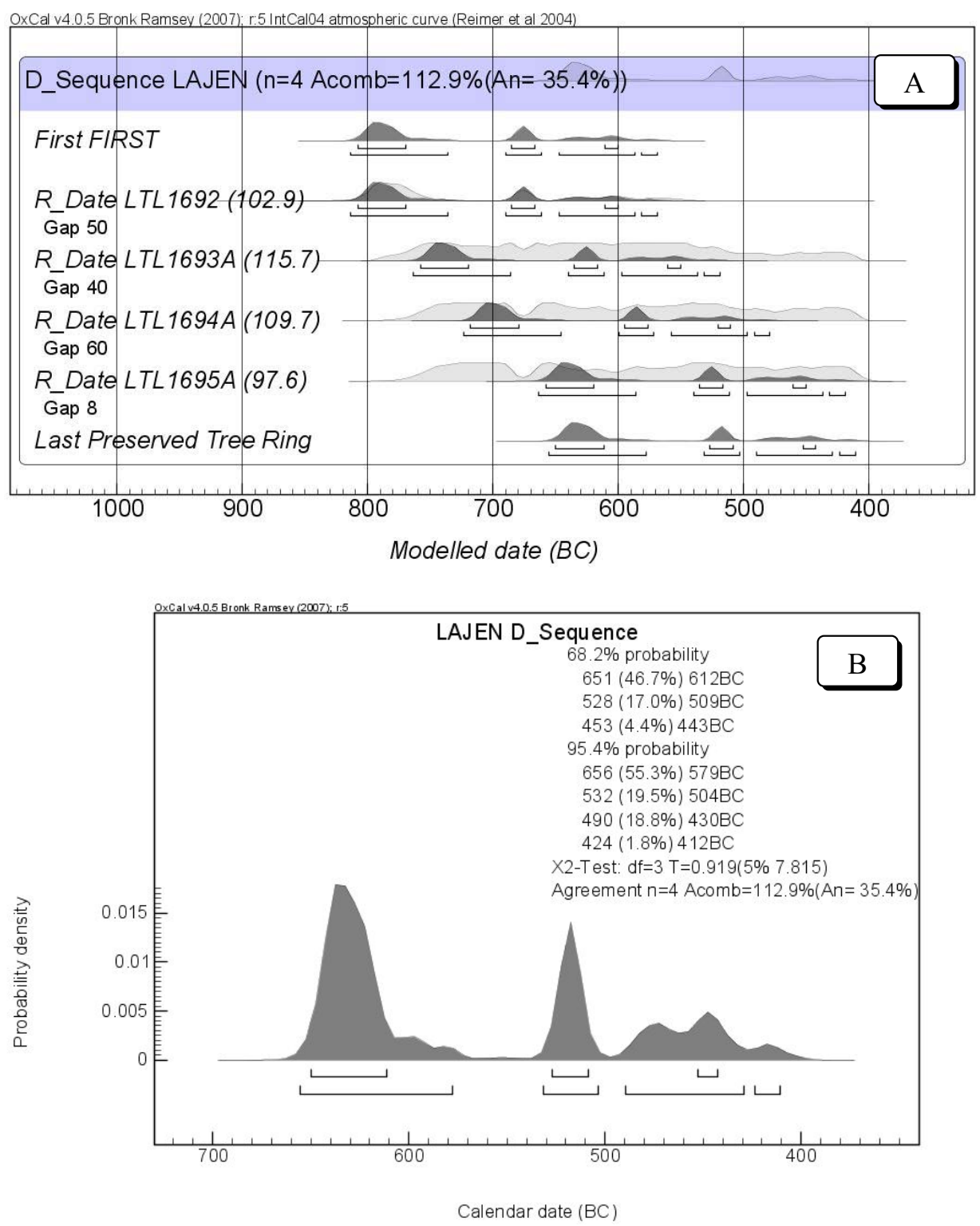

Figure 3 Wiggle-matching results for all samples (A) and for the last preserved ring (B) for the sequence from Laion/Lajen.

\section{CONCLUSIONS}

A ${ }^{14} \mathrm{C}$ wiggle-matching approach was used for dating tree-ring sequences recovered from archaeological excavations in the Stufles and Laion/Lajen sites, South Tyrol, province of Bolzano/Bozen, northern Italy. Samples were recovered from contexts archaeologically dated to the Iron Age (Hallstatt phases D1-D2-D3). ${ }^{14} \mathrm{C}$ results are consistent with the archaeological dating of the structures based on associated material and by dendrochronology. In particular, the ages obtained for the Laion/Lajen site are consistent with the dating to the Ceramic Phase of the ancient culture of Rhae- 
tian-Fritzens-Sanzeno, whose beginning is placed in the late 6th century BC. As with the Laion/ Lajen site, archaeological dating of the building recovered in Stufles is also confirmed by ${ }^{14} \mathrm{C}$ results. Stufles belongs to the Retica culture and thus to phase D of the Hallstatt period. Based on the presented results, future ${ }^{14} \mathrm{C}$ wiggle-match dating campaigns of other ring sequences from the same sites have been planned. They are expected to better define a mean curve for the sites and thus to improve the achievable chronological resolution.

\section{ACKNOWLEDGMENTS}

The assistance provided by the Malcolm and Carolyn Wiener Laboratory for Aegean and Near Eastern Dendrochronology, Cornell University, and in particular the help of Prof Peter Ian Kuniholm, is gratefully acknowledged.

\section{REFERENCES}

Baillie MGL Pilcher JR. 1973. A simple crossdating program for tree-ring research. Tree-Ring Bulletin 33:714.

Bayliss A. 2009. Rolling out revolution: using radiocarbon dating in archaeology. Radiocarbon 51(1):12347.

Blackwell PG, Buck CE, Reimer PJ. 2006. Important features of the new radiocarbon calibration curves. Quaternary Science Reviews 25(5-6):408-13.

Blockley SPE, Blaauw M, Bronk Ramsey C, van der Plicht J. 2007. Building and testing age models for radiocarbon dates in Lateglacial and Early Holocene sediments. Quaternary Science Reviews 26(15-16):191526.

Bronk Ramsey C. 1995. Radiocarbon calibration and analysis of stratigraphy: the OxCal program. Radiocarbon 37(2):425-30.

Bronk Ramsey C. 2001. Development of the radiocarbon calibration program. Radiocarbon 43(2A):355-63.

Bronk Ramsey C. 2009. Bayesian analysis of radiocarbon dates. Radiocarbon 51(1):337-60.

Buck CE, Kenworthy JB, Litton CD, Smith AFM. 1991. Combining archaeological and radiocarbon information: a Bayesian approach to calibration. Antiquity 65(249):808-21.

Bronk Ramsey C, van der Plicht J, Weninger B. 2001. 'Wiggle matching' radiocarbon dates. Radiocarbon 43(2A):381-9.

Calcagnile L, Quarta G. 2010. E/Q and ME/Q² contributions to machine background in sequential injection radiocarbon AMS. Nuclear Instruments and Methods in Physics Research B 268(7-8):830-3.

Calcagnile L, Quarta G, D’Elia M. 2005. High resolution accelerator-based mass spectrometry: precision, accuracy and background. Applied Radiation and Isotopes 62(4):623-9.

D’Elia M, Calcagnile L, Quarta G, Rizzo A, Sanapo C, Laudisa M, Toma U, Rizzo A. 2004. Sample preparation and blank values at the AMS radiocarbon facility of the University of Lecce. Nuclear Instruments and Methods in Physics Research B 223-224:278-83.
Eckstein D, Bauch J. 1969. Beitrag zur Rationaisirung eines dendrochronologischen Verfahrens und sur Analyse seiner Aussagericherheit. Forstwissenschaftlich Centralbatt 88:230-50. In German.

Feltrin M, Marconi S, Pezzo MI, Rizzi Zorzi J, Tecchiati U. 2008. Indagini dendrocronologiche su alcuni edifici dell'età del Ferro recentemente scavati a Stufles (Bressanone/Brixen, Prov. Bolzano/Bozen), Via Elvas 12 e 16. Campagne di scavo 2007 e 2008. Annali del Museo Civico di Rovereto 24. p 95-122. In Italian.

Galimberti M, Bronk Ramsey C, Manning SW. 2004. Wiggle-match dating of tree-ring sequences. Radiocarbon 46(2):917-24

Haneca K, Čufar K, Beeckman H. 2009. Oaks, tree-rings and wooden cultural heritage: a review of the main characteristics and applications of oak dendrochronology in Europe. Journal of Archaeological Science 36(1):1-11.

Hollstein E. 1980. Mitteleuropaische Eichenchronologie. Mainz am Rhein: Verlag Phillipp von Zabern.

Kuniholm PI. 2001. Archaeological dendrochronology. Dendrochronologia 20(1-2):63-8.

Manning SW, Weninger B. 1992. A light in the dark: archaeological wiggle matching and the absolute chronology of the close of the Aegean Late Bronze Age. Antiquity 66(252):636-63.

Manning WS, Kromer B, Kuniholm PI, Newton MW. 2001. Anatolian tree-rings and a new chronology for the East Mediterranean Bronze-Iron Ages. Science 294(5551):2532-5.

Marconi S, Pezzo MI, Quarta G, Tecchiati U. 2007. Analisi dendrocronologica di reperti lignei provenienti dall'abitato della media età del Ferro di Laion/Lajen (Bolzano/Bozen). Annali del Museo Civico di Rovereto 23. $\mathrm{p}$ 73-88. In Italian.

Nicolussi K, Kaufmann M, Melivi TM, van der Plicht J, Schiessling P, Thurner A. 2009. A 9111 year long conifer tree-ring chronology for the European Alps: a base for environmental and climatic investigations. The Holocene 19(6):909-20.

Pezzo MI. 2009. Dendrochronological research at the 
Rosslauf (Brassanone, Italy). In: Manning SW, Bruce MJ, editors. Tree-Rings, Kings and Old World Archaeology and Environment. Oxford: Oxbow Books. p 517.

Reimer PJ, Baillie MGL, Bard E, Bayliss A, Beck JW, Bertrand CJH, Blackwell PG, Buck CE, Burr GS, Cutler KB, Damon PE, Edwards RL, Fairbanks RG, Friedrich M, Guilderson TP, Hogg AG, Hughen KA, Kromer B, McCormac G, Manning S, Bronk Ramsey C, Reimer RW, Remmele S, Southon JR, Stuiver M, Talamo S, Taylor FW, van der Plicht J, Weyhenmeyer CE. 2004. IntCal04 terrestrial radiocarbon age calibration, 0-26 cal kyr BP. Radiocarbon 46(3):1029-58.
Rinn F. 1996. TSAP, Time Series Analysis and Presentation. Version 3.0. Reference Manual. Heidelberg. URL: http://www.rinntech.de/.

Steier P, Rom W. 2000. The use of Bayesian statistics for ${ }^{14} \mathrm{C}$ dates of chronologically ordered samples: a critical analysis. Radiocarbon 42(2):183-98.

Stuiver M, Polach HA. 1977. Discussion: reporting of ${ }^{14} \mathrm{C}$ data. Radiocarbon 19(3):355-63.

Vasiliev SS, Bokovenko NA, Chugunov KA, Dergachev VA, Sementsov AA, Sljusarenko JU, Zaitseva GI. 2001. Tree ring, "wiggle-matching" and statistics in the chronological studies of Scythian Age sites in Asia. Geochronometria 20:61-8. 